\title{
Fish passes design discharge requirements for successful operation
}

\author{
Christian Wolter 는 https://orcid.org/0000-0002-2819-2900, Christian Schomaker
}

DOI

$\underline{10.1002 / \text { rra.3399 }}$

Original publication date

17 January 2019

Document version

Accepted version

Published in

River Research and Applications

\section{Citation (Vancouver)}

Wolter C, Schomaker C. Fish passes design discharge requirements for successful operation. River Research and Applications. 2019;35(10):1697-701. 
Fish passes design discharge requirements for successful operation

Short title: Fish passes design discharge

Christian Wolter and Christian Schomaker

Leibniz-Institute of Freshwater Ecology and Inland Fisheries, Müggelseedamm 310 12587 Berlin, Germany

Corresponding author: Christian Wolter, Phone: +49-30-64181633, Fax: +49-30-64181750, Email: wolter@igb-berlin.de

\begin{abstract}
Longitudinal connectivity is one of the prime issues addressed in river restoration our days. At the same time mitigation of climate change impacts by modes or renewable energy increasingly puts pressure on the remaining free flowing river stretches for hydroelectricity production. At the site level this trade-off manifests in the negotiation of water for upstream and downstream fish passage versus losses for hydroelectricity production. This study has compiled and analysed 193 studies evaluating fish passes designed to provide upstream migration for all species and size classes of the respective river system. The overall assessment of functioning as well as discharge dedicated to fish pass maintenance, site and river characters were provided by the studies. The main objective here was deriving general guidance for the minimum amount of water needed fully functioning upstream fish passage in relation to river size. There was a significant correlation between functionality and design discharge of a fish pass. Fully functioning fish passes $(\mathrm{N}=92)$ had median design discharge of $5 \%$ of the mean average discharge of the river, restrictedly functioning of $1.1 \%$ and not functioning of $0.22 \%$. A power model could be derived of design discharge needs in relation to river discharge which is inversely related to river size. In large rivers a rather small share of mean discharge is sufficient; while in small rivers cannot be further downscaled due to dimensions. This model might provide first guidance in adjusting needs for both hydroelectricity generation and fish conservation in regulated rivers.
\end{abstract}

Keywords: longitudinal connectivity, river rehabilitation, fish pass, design discharge

\title{
INTRODUCTION
}

Migration barriers and habitat fragmentation have long been identified as major impacts on riverine aquatic ecosystems resulting in dramatic declines of obligatory migrating fish species (Dugan et al., 2010; Limburg and Waldman, 2009) as well as riverine fish in general (Pimm et al., 1995; Wilcove et al., 1998; Dugan et al., 2010). Worldwide, there are between 37,626 (ICOLD, 2011) and >45,000 (Nilsson et al., 2005) large dams higher than $15 \mathrm{~m}$ registered. Lehner et al. (2011) estimated that about $7.6 \%$ of the world's rivers with an average discharge $>1$ 
$\mathrm{m}^{3} / \mathrm{s}(575,900$ river kilometres) is affected by a cumulative upstream reservoir capacity that exceeds $2 \%$ of their annual flow. However, the number of large dams and reservoirs significantly underestimates the ecological impacts of damming on aquatic organisms, because already barriers $>0.2 \mathrm{~m}$ height can form impassable obstacles for some fish and lamprey species and their number is multiply higher. For example, in the United States the total number of migration barriers comprises 74,921 dams $>2 \mathrm{~m}$ high (Graf, 1999) and more than two million smaller dams (Poff and Hart, 2002). In Austrian rivers 55,135 small dams and weirs were reported (Lashofer et al., 2011), in German rivers some 200,000 transverse structures (Fehér et al., 2012). Other recent counts of river fragmentation in Europe provided by Fehér et al. (2012) comprise: more than 60,000 dams, weirs and mills on French rivers, over 100,000 artificial barriers with a height $>0.5$ $\mathrm{m}$ in Swiss rivers, 779 barriers on the $3000 \mathrm{~km}$ long priority network of rivers in Belgium, 6023 barriers $>1 \mathrm{~m}$ in height in Czech rivers, and 1688 continuity interruptions in the River Danube. In the Netherlands approximately 18,000 potential barriers are located in WFD (European Water Framework Directive, 2000/60/EC) relevant water bodies (Brevé et al., 2014).

However, despite the already overwhelming global river fragmentation and its well-known impact on aquatic biodiversity, there is an increasing pressure on the last free flowing river sections for hydroelectricity production, especially in Southeast Asia, South America, and Africa (Zarfl et al., 2015). The Paris Agreement to combat climate change and to accelerate actions for a sustainable low carbon future of December 12, 2015 has now been ratified by 175 parties. It requires the parties to lower their greenhouse gas emissions and to meet their growing energy demand from renewable sources. This will drive further development of hydropower as one source of renewable energy, especially because its technically feasible potential has been estimated exploited by $22 \%$ only globally (ICOLD, 2011). Correspondingly, in the United States rising energy consumption in coming decades in combination with improving renewable energy production have been projected to increase the annual water withdrawn or manipulated especially for hydropower by 18-24\% (McDonald et al., 2012). In Europe, the European Commission proposed a Renewable Energy Directive (RED, 2009/28/EC) aiming to increase the level of renewable energy - among others from hydropower - in the EU energy mix to $20 \%$ by 2020 . Accordingly, National legislations like the German Renewable Energy Act (EEG) have been amended setting incentives to increase the amount of renewable energies, e.g. higher feed-in tariffs for energy generated from small hydropower and other renewable sources. By stimulating renewable energy production from hydropower and the full exploration of the hydropower potential of rivers (Anderer et al., 2010; Anderer, 2011), the implementation of RED worsens the ecological status of rivers. Increasing hydroelectricity production will compromise the biodiversity conservation goals.

At the local scale, similar trade-off manifests due to water demands for upstream fish migration and downstream fish protection facilities, which are lost for electricity production. There is a strong interest from the hydroelectricity producers to keep such losses at minimum, which usually results in the provision of no or insufficient ecological connectivity. This study focuses on fish migration as the most often addressed aspect of longitudinal connectivity. 
Numerous documents and handbooks provide guidance on how to design and construct a fish pass, where to position it, and how to guide and attract upstream migrating fish (e.g., Clay, 1995; Jungwirth et al., 1998; MUNLV, 2005; DWA, 2014). There are also several studies and reviews on the assessment of fish pass efficiency, which is generally a function of attraction and passability (e.g., Bourne et al., 2011; Bunt et al., 2012; 2016). Therefore, this study neither addresses efficiency assessment of fish passes nor construction details. The focus here is on the design discharge assigned for fish passes independent of their type. Many typical failures reported for fish passes like insufficient attraction flow, too narrow slots, too steep slopes causing too high flow velocities and height differences between compartments of the fish pass, are all directly or indirectly related to insufficient water supply assigned already in the planning phase. There are no rules established on the minimum amount of water to supply unhindered fish migration. Therefore, this study aimed to derive a first estimate for fish pass design discharge, i.e. for the share of average river flow needed for unrestricted upstream fish migration from existing evaluation studies.

\section{DATA COLLECTION}

Scientific and grey literature was searched for fish pass evaluation studies using common search engines with "fish pass*", "longitudinal connect*" and "fish", "migration facility" and "fish", respectively the German terms "Fischpas*" and "Durchgäng*" and "Fisch" as keywords. The reference lists of obtained work were screened for original data and further sources. In addition, a request for unpublished reports and documents has been sent to the German Federal authorities responsible for water, environmental planning, and nature conservation, because they often request for success monitoring from fish pass constructors.

All texts were screened for information on fish pass details, hydraulic design, dimensions, especially flow over the fish pass, success monitoring, passage rates, constraints, and final assessment. A principal pre-requisite for inclusion in the study was that the fish pass was designed to serve all species and age groups corresponding to recent guidance for longitudinal connectivity in Europe and elsewhere, which require for unrestricted passage of all species and age groups including weak swimmers (MUNLV, 2005; DWA, 2014). This approach automatically excluded eel ladders and Denil fish passes, which by design serve only a single species and large salmonids, respectively. A study was retained for further analyses if the following minimum information was provided: i) a final assessment of the upstream fish passage based on observational data from no to fully functioning, ii) the type of fish pass, iii) the maximum discharge through the fish pass (here considered as design discharge), and iv) the mean discharge of the river at the site or the fish region. Additional information on fish pass design, dimensions, age, slope, depth, flow velocities, and energy dissipation have been compiled when provided together with the information on river and site name, country and continent.

Our search yielded a total of 79 studies reporting on 193 upstream fish migration facilities. The database is provided as supplemental material. 
The rather low number of evaluable studies is in accordance with former findings (e.g., Roscoe and Hinch, 2010; Bunt et al., 2012; Noonan et al., 2012; Pompeu et al., 2012). The vast majority of fish passes have never been evaluated and will never be evaluated, although thousands of fish passes exist worldwide and improving longitudinal connectivity is high on the river rehabilitation agenda, e.g. in Germany (Kail and Wolter, 2011) and the Netherlands (Brevé et al., 2014),

\section{DATA ANALYSES}

The ratio between the reported maximum discharge through the fish pass $\left(\mathrm{Q}_{\mathrm{FP}}\right)$ and the mean river discharge (MQ) was computed. The $\mathrm{Q}_{\mathrm{FP}} / \mathrm{MQ}$ ratio was $\arcsin -\operatorname{transformed}(\arcsin (\operatorname{sqrt}(\mathrm{x})))$ and MQ $\log (\lg (\mathrm{x}))$ transformed. For fish passes allowing full passage a regression model was calculated of $\mathrm{Q}_{\mathrm{FP}}$ in relation to $\mathrm{MQ}$ as proxy for river size using the transformed values. A power function fitted best.

Fully functioning and not functioning were used as provided by the various studies, while all reported limitations (size or species selectivity and insufficient numbers of upstream migrants) were considered restricted passability.

Fish pass types were classified according to their principal construction into pool type, vertical slot, bottom ramp passes, and bypass channels, to mention the most common types.

Significant differences in mean $\mathrm{Q}_{\mathrm{FP}} / \mathrm{MQ}$ ratios between types of fish passes respectively fish passage functionality classes were tested using one-way ANOVA with post hoc Dunnet-T3 test due to variance inhomogeneity. The comparison between fish pass types was limited to bottom

ramps, bypasses, pool and vertical slot fish passes, because of low numbers of replicates for other types ( $9 \mathrm{~V}$-stepped passes, 6 meander fish passes, 4 bristles passes, 3 fish lifts and 3 fish locks). To assess the impact of $\mathrm{Q}_{\mathrm{FP}} / \mathrm{MQ}$ ratio on upstream fish passage function a median test (KruskalWallis H) was performed with post hoc Mann-Whitney U pairwise comparisons.

All calculations were performed using IBM SPSS Statistics Version 22.

\section{RESULTS}

The 193 fish pass assessments were mainly obtained from Europe (176), in particular from Germany (119), Austria (26) and Switzerland (15). Ten studies were found from Australia, five from South America and one each from North America and Asia. The river systems ranged from small creeks with mean discharge of $0.07 \mathrm{~m}^{3} / \mathrm{s}$ to large rivers with $12,000 \mathrm{~m}^{3} / \mathrm{s}$. The fish passes had dotations between $0.04 \mathrm{~m}^{3} / \mathrm{s}$ and $12 \mathrm{~m}^{3} / \mathrm{s}$. The resulting $\mathrm{Q}_{\mathrm{FP}} / \mathrm{MQ}$ ratios ranged between $0.002 \%$ and $100 \%$ (mean \pm standard deviation $=25.8 \pm 39.4 \%$, median $=2.61 \%$ ).

The majority of fish passes evaluated were pool type fish passes (51), followed by bottom ramps (45), bypass channels (38), and vertical slot passes (34). Pool type fish passes performed significantly less than other fish passes (one way ANOVA, $\mathrm{p}<0.01$ ).

Most of the evaluated fish passes were reportedly fully functioning, about one third restrictedly and 33 not at all (Fig. 1). Bottom ramps, bypass channels, and vertical slot passes had the highest share fully functioning migration facilities (Table 1). The fully functioning fish passes received discharges between $0.068 \mathrm{~m}^{3} / \mathrm{s}$ and $6.5 \mathrm{~m}^{3} / \mathrm{s}$ (min-max) and were situated in a broad variety of 
rivers ranging from $0.106 \mathrm{~m}^{3} / \mathrm{s}$ to $1910 \mathrm{~m}^{3} / \mathrm{s}$ MQ (Supplementary information). The group of fish passes reportedly not functioning received significantly lower $\mathrm{Q}_{\mathrm{FP}}$ (one way ANOVA, $\mathrm{p}<0.01$ ). The median $\mathrm{Q}_{\mathrm{FP}}$ was $5 \%$ of the river's MQ for fully functioning fish passes, $1.1 \%$ for restrictedly functioning and only $0.22 \%$ for not functioning fish passes. These differences were highly significant between all three groups (Kruskal-Wallis $\mathrm{H}, \mathrm{p}<0.001$, Mann-Whitney $\mathrm{U}, \mathrm{p}<0.05$ ).

Bottom ramps received significantly higher $\mathrm{Q}_{\mathrm{FP}} / \mathrm{MQ}$ ratios than bypasses and vertical slot passes (one way ANOVA, p < 0.01, Fig. 2); however, their reported performance in fish passage did not significantly differ (one way ANOVA, $\mathrm{p}>0.2$ ). Pool type fish passes were maintained with significantly lower $\mathrm{Q}_{\mathrm{FP}} / \mathrm{MQ}$ ratios (Kruskal-Wallis $\mathrm{H}, \mathrm{p}<0.001$ ) compared to other fish pass types (Fig. 2), which coincides with their significantly lower performance.

The median $\mathrm{Q}_{\mathrm{FP}} / \mathrm{MQ}$ ratio of the fully functioning fish passes was $5 \%$ of the average river discharge (range 0.04-100\%, mean \pm standard deviation $=32.6 \pm 42.4 \%$ ). Over all types of fish passes their functionality in terms of fish passage was positively correlated to the $\mathrm{Q}_{\mathrm{FP}} / \mathrm{MQ}$ ratio (Fig. 1), however, this relation is highly significantly, inversely correlated to river size (Fig. 3). Meaning in large rivers a rather small share of the mean discharge is sufficient to provide successful upstream fish passage, while this proportion exponentially increases in small rivers. In contrast, in small rivers the absolute minimum size of a migration facility in terms of depth, slot width and flow necessary to attract a fish and let him pass through cannot be further downscaled and thus, requires higher shares of the available discharge for maintenance.

\section{DISCUSSION}

Despite tremendous efforts and a huge amount of projects to improve longitudinal connectivity of rivers for fish, there were surprisingly few studies evaluating the efficiency of upstream fish passage for a variety of species and size classes in relation to discharge. Similar deficits were reported by Roscoe and Hinch (2010); Bunt et al. (2012; 2016), Noonan et al. (2012), and Pompeu et al., 2012). This study compiled and analysed a representative data set of 193 fish pass assessments covering a broad range of river types from small creeks to very large rivers (Supplemental material). There is a spatial bias by studies from Europe, which is less related to accessibility of studies rather than the longer tradition of providing fish passage for all species and size classes. For example, in North America fish passes primarily designed for salmons and to a lesser degree for shads and sturgeons, while coarse fish migration needs are not addressed (Roscoe and Hinch, 2010; Katopodis and Williams, 2012). This analyses on purpose focused on the fish assemblage as a whole.

There are no general standards or agreements in fish pass assessment on when a fish pass is fully functioning (Roscoe and Hinch, 2010; Bourne et al., 2011) illustrated by recent debates (Bunt et al., 2012; 2016; Kemp, 2016, Williams and Katopodis, 2016). The various studies applied different methods to assess fish pass functionality, but all had in common that the evaluation based on direct observations or catches. They probably differed in scoring the numbers of successfully upstream migrating specimens observed, but we did not analyse how substantiated the reported assessment results were. However, corresponding to a recent evaluation of 
differences in expert judgement of habitat suitability for fish (Radinger et al., 2017) we might assume that the agreement in assessing a fish pass as fully or not passable between the studies is very high, while the assessment of selectivity and sufficient migration rates might vary. The latter variation will not influence our results much, because we did not further differentiated between restrictedly passable fish passes in our analyses.

Corresponding to the different scoring systems also the variety of potential failures, which were reported for about one third of the studies was not further analysed. Individual construction failures like larger height differences between pools, too high flow velocities in slots, too shallow flows over bars, too small pools or insufficient energy dissipation or even wrong location of the fish pass entrance and lack of attraction flow can impede successful fish passage (Clay, 1995; MUNLV, 2005; Williams et al., 2012; DWA, 2014). All these aspects alone or in combination apply also for the fish pass evaluations analysed, but still $\mathrm{Q}_{\mathrm{FP}} / \mathrm{MQ}$ ratio emerged as significant predictor of fish pass efficiency.

Therefore, despite all limitations, the result obtained seems rather robust. The study yielded clear evidence for the positive relation between functioning and the maximum discharge through the fish pass. The overall $\mathrm{Q}_{\mathrm{FP}} / \mathrm{MQ}$ ratio of a functioning fish pass compared to the river size was unexpectedly low, but plausible. For example, the minimum dimensions of a fish pass needed for brown trout are determined by the size of a mature specimen (MUNLV, 2005; DWA, 2014), so that with decreasing river size and discharge the $\mathrm{Q}_{\mathrm{FP}} / \mathrm{MQ}$ ratio increases. In contrast, in large rivers even a rather low $\mathrm{Q}_{\mathrm{FP}} / \mathrm{MQ}$ ratio may result in significant absolute discharge causing expensive constructions. Higher absolute $\mathrm{Q}_{\mathrm{FP}}$ is also needed to mimic the typical flow conditions of a river, especially of large lowland rivers. Fish species used to migrate and spawn in large, low energy river corridors, as e.g. shads, smelt, will behaviourally resist and avoid entering high energy fish passes. This became for example obvious with the opening of the new, much larger fish pass at weir Geesthacht, River Elbe, Germany, which now facilitates upstream migration of smelt, little flounders, sticklebacks and other potamal fish species (Adam et al., 2012).

The findings presented here provide some guidance for determining $\mathrm{Q}_{\mathrm{FP}} / \mathrm{MQ}$ ratio of fish passes at about $5 \%$ of the mean flow of the river, with higher proportions in smaller rivers and vice versa. Further research is needed to adjust the balance between the maximum $\mathrm{QFP}_{\mathrm{FP}} / \mathrm{MQ}$ ratio feasible and full fish passage for different river types.

\section{ACKNOWLEDGMENT}

This work was funded by the German Federal Ministry for the Environment, Nature Conservation, Building and Nuclear Safety under the project grant $0325531 \mathrm{C}$.

\section{REFERENCES}

Adam B, Faller M, Gischkat S, Hufgard H, Löwenberg S, Mast N. 2012. Ergebnisse nach einem Jahr fischökologischen Monitorings am Doppelschlitzpass Geesthacht. WasserWirtschaft 4/2012: 49-57. 
Anderer P. 2011. Das Wasserkraftpotenzial in Deutschland und Europa. WasserWirtschaft 101 (10): 13-16.

Anderer P, Dumont U, Heimerl S, Ruprecht A, Wolf-Schumann U. 2010. Das Wasserkraftpotenzial in Deutschland. WasserWirtschaft 100 (9): 12-16.

Bourne C, Kehler D, Wiersma Y, Cote D. 2011. Barriers to fish passage and barriers to fish passage assessments: the impact of assessment methods and assumptions on barrier identification and quantification of watershed connectivity. Aquatic Ecology 45: 389-403. Doi: $10.1007 / \mathrm{s} 10452-011-9362-\mathrm{z}$

Brevé NWP, Buijse AD, Kroes MJ, Wanningen H, Vriese FT. 2014. Supporting decision-making for improving longitudinal connectivity for diadromous and potamodromous fishes in complex catchments. Science of the Total Environment 496: 206-218. Doi: 10.1016/j.scitotenv.2014.07.043

Bunt CM, Castro-Santos T, Haro A. 2012. Performance of fish passage structures at upstream barriers to migration. River Research and Applications 28: 457-478. Doi: 10.1002/rra.1565

Bunt CM, Castro-Santos T, Haro A. 2016. Reinforcement and Validation of the Analyses and Conclusions Related to Fishway Evaluation Data from Bunt et al.: 'Performance of Fish Passage Structures at Upstream Barriers to Migration'. River Research and Applications 32: 2125-2137. Doi: 10.1002/rra.3095

Clay CH. 1995. Design of Fishways and Other Fish Facilities. Lewis Publishers: Boca Raton.

Dugan PJ, Barlow C, Agostinho AA, Baran E, Cada GF, Chen D, Cowx IG, Ferguson JW, Jutagate T, Mallen-Cooper M, Marmulla G, Nestler J, Petrere M, Welcomme RL, Winemiller KO. 2010. Fish migration, dams, and loss of ecosystem services in the Mekong Basin. Ambio 39: 344-348. Doi: 10.1007/s13280-010-0036-1

Dudgeon D. 2011. Asian river fishes in the Anthropocene: threats and conservation challenges in an era of rapid environmental change. Journal of Fish Biology 79: 1487-1524. Doi: 10.1111/j.1095-8649.2011.03086.x

DWA 2014. Fischaufstiegsanlagen und fischpassierbare Bauwerke - Gestaltung, Bemessung, Qualitätssicherung. DWA-M 509. Deutsche Vereinigung für Wasserwirtschaft, Abwasser und Abfall e.V. (DWA): Hennef. 
Fehér J, Gáspár J, Szurdiné-Veres K, Kiss A, Kristensen P, Peterlin M, Globevnik L, Kirn T, Semerádová S, Künitzer A, Stein U, Austnes K, Spiteri C, Prins T, Laukkonen E, Heiskanen A-S. 2012. Hydromorphological alterations and pressures in European rivers, lakes, transitional and coastal waters. Thematic assessment for EEA Water 2012 Report. ETC/ICM Technical Report 2/2012, European Topic Centre on Inland, Coastal and Marine Waters: Prague.

Graf WL. 1999. Dam nation: A geographic census of American dams and their large-scale hydrologic impacts. Water Resources Research 35: 1305-1311. Doi: 10.1029/1999WR900016

ICOLD 2011. World Register of Dams. International Commission on Large Dams (ICOLD): Paris, http://www.icold-cigb.org/GB/World_register/general_synthesis.asp, last access 11.07.2018.

Jungwirth M, Schmutz S, Weiss S. (eds). 1998. Fish Migration and Fish Bypasses. Fishing News Books, Blackwell Science: Oxford.

Kail J, Wolter C. 2011. Analysis and evaluation of large-scale river restoration planning in Germany to better link river research and management. River Research and Applications 27: 985999. Doi: $10.1002 /$ rra.1382

Katopodis C, Williams JG. 2012. The development of fish passage research in a historical context. Ecological Engineering 48: 8-18. Doi: 10.1016/j.ecoleng.2011.07.004

Kemp PS. 2016. Meta-analyses, Metrics and Motivation: Mixed Messages in the Fish Passage Debate. River Research and Applications 32: 2116-2124. Doi: 10.1002/rra.3082

Lashofer A, Hawle W, Cassidy T, Pucher M, Fürst J, Pelikan B. 2011. Wasserkraft als Sanierungsmotor für hydromorphologische Belastungen? WasserWirtschaft 101 (7-8): 42-47.

Lehner B, Liermann CR, Revenga C, Vorosmarty C, Fekete B, Crouzet P, Doll P, Endejan M, Frenken K, Magome J, Nilsson C, Robertson JC, Rodel R, Sindorf N, Wisser D. 2011. Highresolution mapping of the world's reservoirs and dams for sustainable river-flow management. Frontiers in Ecology and the Environment 9: 494-502. Doi: 10.1890/100125

Limburg KE, Waldman JR. 2009. Dramatic declines in North Atlantic diadromous fishes. BioScience 59: 955-965. Doi: 10.1525/bio.2009.59.11.7

McDonald RI, Olden JD, Opperman JJ, Miller WM, Fargione J, Revenga C, Higgins JV, Powell J. 2012. Energy, water and fish: biodiversity impacts of energy-sector water demand in the 
United States depend on efficiency and policy measures. PLOS ONE 7(11): e50219. Doi: 10.1371/journal.pone.0050219

MUNLV 2005. Handbuch Querbauwerke. Ministerium für Umwelt und Naturschutz, Landwirtschaft und Verbraucherschutz des Landes Nordrhein-Westfalen (MUNLV): Düsseldorf.

Nilsson C, Reidy CA, Dynesius M, Revenga C. 2005. Fragmentation and flow regulation of the World's large river systems. Science 308: 405-408. Doi: 10.1126/science.1107887

Noonan MJ, Grant JWA, Jackson CD. 2012. A quantitative assessment of fish passage efficiency. Fish and Fisheries 13: 450-464. Doi: 10.1111/j.1467-2979.2011.00445.x

Pimm SL, Russell GJ, Gittleman JL, Brooks TM. 1995. The future of biodiversity. Science 269: 347-350. Doi: 10.1126/science.269.5222.347

Poff NL, Hart DD. 2002. How dams vary and why it matters for the emerging science of dam removal. BioScience 52: 659-668. Doi: 10.1641/0006-3568(2002)052

Pompeu PS, Agostinho AA, Pelicice FM. 2012. Existing and future challenges: the concept of successful fish passage in South America. River Research and Applications 28: 504-512. Doi: 10.1002/rra.1557

Radinger J, Kail J, Wolter C. 2017. Differences among expert judgments of fish habitat suitability and implications for river management. River Research and Applications 33: 538-547. Doi:10.1002/rra.3109

Roscoe DW, Hinch SG. 2010. Effectiveness monitoring of fish passage facilities: historical trends, geographic patterns and future directions. Fish and Fisheries 11: 12-33. Doi: 10.1111/j.1467-2979.2009.00333.x

Wilcove DS, Rothstein D, Dubow J, Phillips A, Loscos E. 1998. Quantifying threats to imperiled species in the United States. BioScience 48: 607-615. Doi: 10.2307/1313420

Williams JG, Katopodis C. 2016. Commentary - Incorrect application of data negates some meta-analysis results in Bunt et al. (2012). River Research and Applications 32: 2109-2115. Doi: 10.1002/rra.3076

Williams JG, Armstrong G, Katopodis C, Larinier M, Travade F. 2012. Thinking like a fish: a key ingredient for development of effective fish passage facilities at river obstructions. River Research and Applications 28: 407-417. Doi: 10.1002/rra.1551 
Zarfl C, Lumsdon A, Berlekamp J, Tydecks L, Tockner K. 2015. A global boom in hydropower dam construction. Aquatic Sciences 77: 161-170. Doi: 10.1007/s00027-014-0377-0

Table 1 Average $\mathrm{Q}_{\mathrm{FP}} / \mathrm{MQ}$ ratios of reportedly fully to not functioning fish passes per fish pass type (in parentheses number of observations)

\begin{tabular}{llll}
\hline Fish pass type & \multicolumn{3}{c}{ Fish passability reported } \\
\cline { 2 - 4 } & full & restricted & no \\
\hline Bottom ramp & $0.733(28)$ & $0.978(14)$ & $0.418(3)$ \\
Bristles pass & $0.539(2)$ & $0.048(2)$ & \\
Bypass & $0.139(20)$ & $0.200(11)$ & $0.108(7)$ \\
Fish lift & $0.045(1)$ & $0.000(1)$ & $0.001(1)$ \\
Fish lock & $0.031(1)$ & $0.004(2)$ & \\
Meander pass & $0.031(3)$ & $0.108(3)$ & \\
Pool pass & $0.071(7)$ & $0.008(23)$ & $0.017(21)$ \\
Vertical slot & $0.170(21)$ & $0.072(12)$ & $0.021(1)$ \\
V-stepped & $0.149(9)$ & & \\
\hline
\end{tabular}

Figure legends

Figure 1. Reported fish pass functionality for upstream migration in relation to the $\mathrm{Q}_{\mathrm{FP}} / \mathrm{MQ}$ ratio (number of samples in parentheses). Same superscripts refer to homogenous subgroups (KruskalWallis H Test, $\mathrm{df}=2, \chi^{2}=11.097, \mathrm{p}<0.001$, post hoc Mann-Whitney $\left.\mathrm{U}\right)$.

Figure 2. Relative design discharges $\left(\mathrm{Q}_{\mathrm{FP}} / \mathrm{MQ}\right.$ ratios) reported for different fish pass types (number of samples). Same superscripts refer to homogenous subgroups (Kruskal-Wallis H Test, $\mathrm{df}=3, \chi^{2}=32.33, \mathrm{p}<0.001$, post hoc Mann-Whitney $\mathrm{U}$ ).

Figure 3. Regression (power model) of fish pass design discharges (\%MQ, arcsin-transformed) in relation to mean river discharge $\left(\mathrm{m}^{3} / \mathrm{s}, \log\right.$-transformed) for fish passes reported fully functioning $(\mathrm{N}=92)$. 


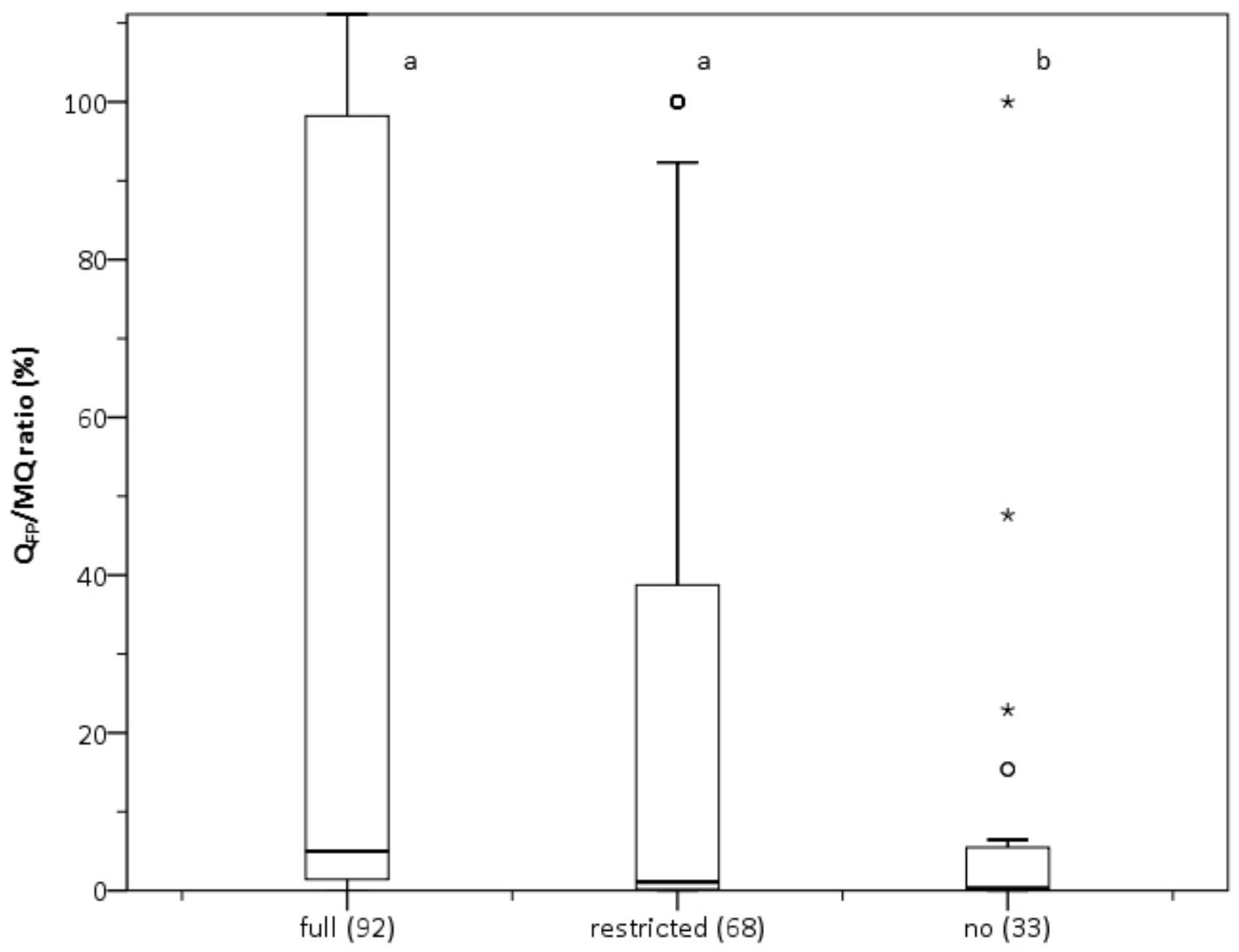

Fish passability reported 


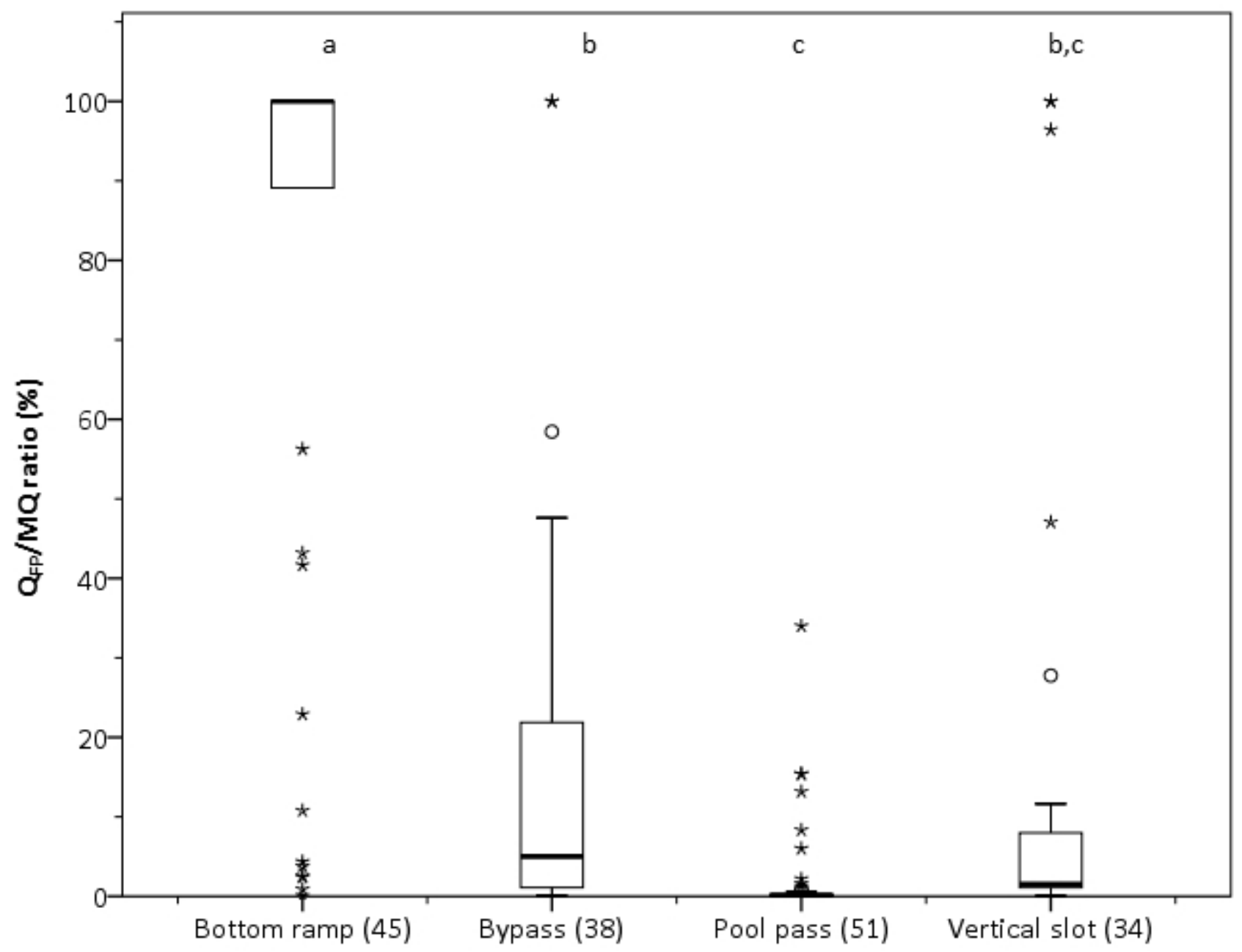




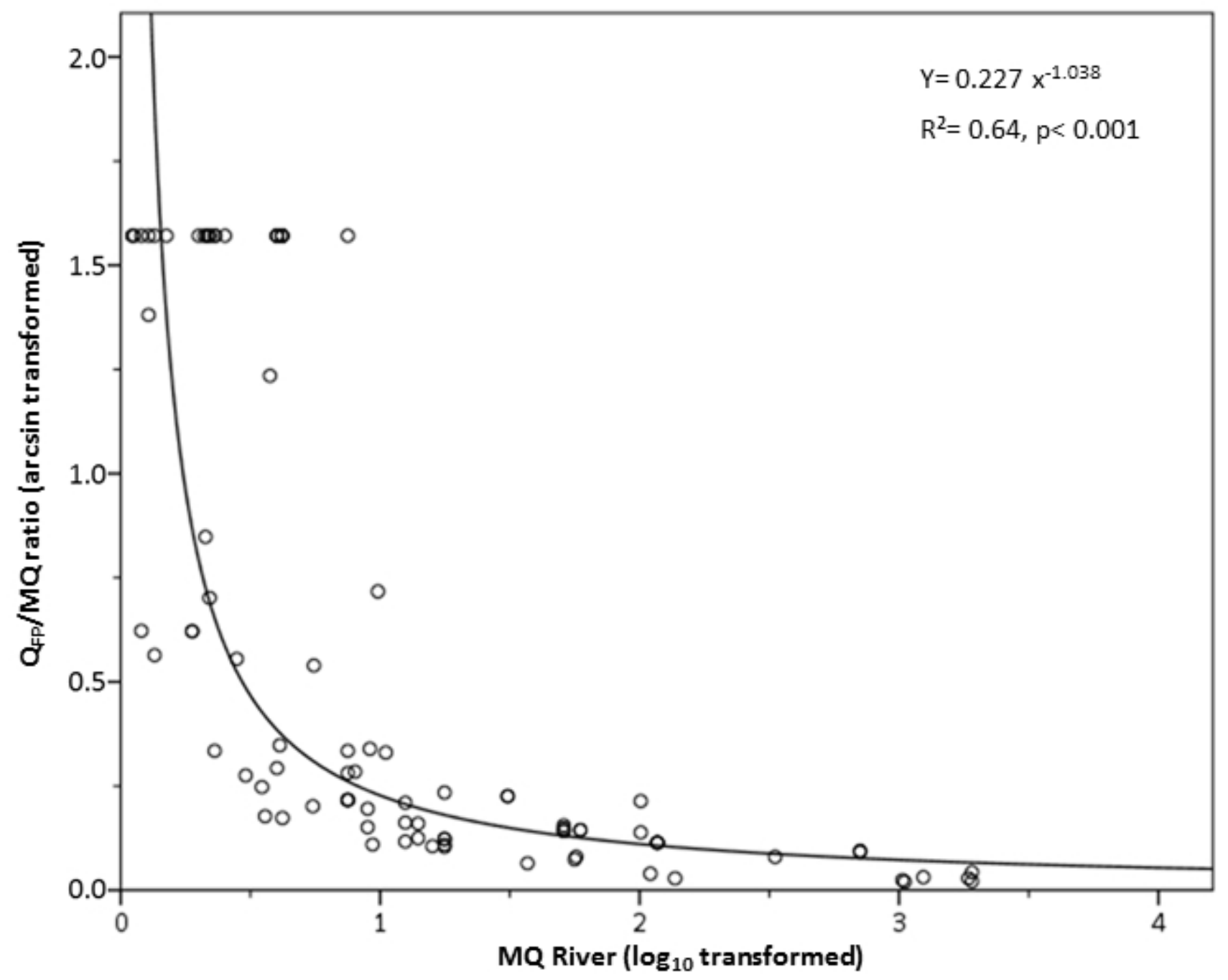

